\title{
Paroxysmal kinesigenic dyskinesia: a frequently misdiagnosed movement disorder
}

\author{
Vivek Junewar, Ritesh Sahu, Rakesh Shukla
}

Department of Neurology, King George's Medical University, Lucknow, Uttar Pradesh, India

\section{Correspondence to} Professor Rakesh Shukla, rakeshshukla_rakesh@ rediffmail.com

Accepted 27 January 2014
CrossMark

To cite: Junewar V, Sahu R,
Shukla R. BMJ Case Rep
Published online: [please
include Day Month Year]
doi:10.1136/bcr-2014-
203681

To cite: Junewar $V$, Sahu $R$, Shukla R. BMJ Case Rep Published online: please doi:10.1136/bcr-2014203681

\section{DESCRIPTION}

A 13-year-old boy previously diagnosed as having psychogenic movement disorder presented with a 2-year history of episodic dystonic movements involving all limbs and face. The episodes were precipitated by sudden movements, lasted for less than $30 \mathrm{~s}$, occurring 5-6 times/day and were preceded by tingling sensations (video 1). There was no history of any major medical or surgical illness. Family history was negative. Physical examination of the patient did not reveal any abnormality.

Owing to distinctive semiology of the abnormal movements and particularly it being triggered by sudden movement, we strongly thought of the possibility of paroxysmal kinesigenic dyskinesia (PKD). Other possibilities of epilepsy, tetany and psychogenic movement disorder were also considered. His blood investigations revealed normal serum electrolytes (sodium, potassium, calcium and magnesium), random blood sugar, renal function tests and liver function tests. CT of the brain and EEG were also normal.

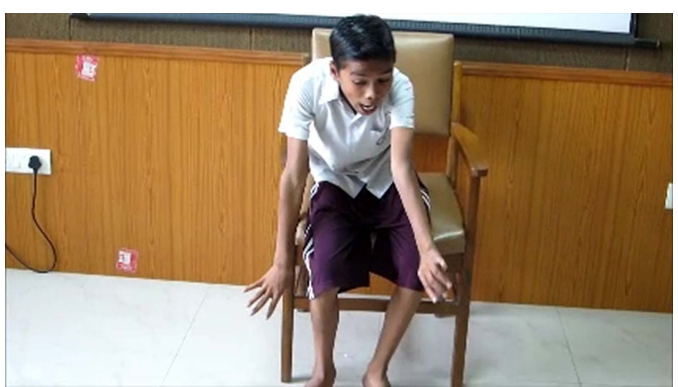

Video 1 Dystonic movements involving all limbs and face precipitated by sudden movements and lasting for less than 30 seconds
Keeping a possibility of PKD, the patient was started on carbamazepine. The patient's symptoms responded completely to the treatment.

PKD is a frequently misdiagnosed, rare movement disorder comprising episodes of dystonia or choreoathetotic movements precipitated by sudden movement, lasting for $<1 \mathrm{~min}$ with preserved consciousness. ${ }^{12}$

\section{Learning points}

- Paroxysmal kinesigenic dyskinesia is frequently misdiagnosed as psychogenic movement disorder unless one is aware of.

- Its diagnosis is important as it is one of the easily treatable movement disorders.

- Neuroimaging and electroencephalography should be done to exclude other common differential diagnosis.

Contributors RS contributed to the concept of manuscript and drafting the manuscript. VJ contributed to the concept and reviewing literature. RS contributed to reviewing the literature and revising the manuscript.

\section{Competing interests None.}

Patient consent Obtained.

Provenance and peer review Not commissioned; externally peer reviewed.

\section{REFERENCES}

1 Bruno MK, Hallett M, Gwinn-Hardy K, et al. Clinical evaluation of idiopathic paroxysmal kinesigenic dyskinesia: new diagnostic criteria. Neurology 2004;63:2280-7.

2 Swoboda KJ, Soong BW, McKenna C, et al. Paroxysmal kinesigenic dyskinesia and infantile convulsions. Clinical and linkage studies. Neurology 2000;55:224-30.

Copyright 2014 BMJ Publishing Group. All rights reserved. For permission to reuse any of this content visit http://group.bmj.com/group/rights-licensing/permissions.

BMJ Case Report Fellows may re-use this article for personal use and teaching without any further permission.

Become a Fellow of BMJ Case Reports today and you can:

- Submit as many cases as you like

- Enjoy fast sympathetic peer review and rapid publication of accepted articles

- Access all the published articles

- Re-use any of the published material for personal use and teaching without further permission

For information on Institutional Fellowships contact consortiasales@bmjgroup.com

Visit casereports.bmj.com for more articles like this and to become a Fellow 